\section{Ivana Simić}

University of Niš, Faculty of Economics
ORIGINAL SCIENTIFIC ARTICLE doi: $10.5937 /$ ekonomika2003001S

Received: January, 15. 2020.

Accepted: May, 14. 2020

\title{
ARE MANAGERS AND LEADERS ONE AND THE SAME?²
}

\begin{abstract}
Although the debate about the relationship between management/manager and leadership/leader has been present in management science for decades, there is still no final general agreement about the character of the mentioned relationship. For many years the prevailing approach, according to which there is no relevant equality between management/manager and leadership/leader, has been replaced with a different one which highlights the high level of overlaping and similarity between the mentioned categories. In this paper, these two approaches are only conditionally labeled as traditional and contemporary. Accordingly, the key features of both these approaches are presented. The author of the paper considers that all these analyses of the relationship between management/manager and leadership/leader, which do not take into account the fact that within an organization it is possible to identify two prominent types of leadership/leaders (formal and informal), are defective and incomplete. The paper emphasizes that the relationship between management/manager and formal leadership/leader is not identical to the relationship between management/manager and informal leadership/leader.
\end{abstract}

Key words: manager, leader, traditional approach, contemporary approach.

JEL classification: M540.

\section{ДА ЛИ СУ МЕНАЏЕРИ И ЛИДЕРИ ЈЕДНО ТЕ ИСТО?}

\section{Апстракт}

Иако је дебата по питању односа између менаимента/менаиера и лидерства/ лидера у менацмент науци присутна већ деценијама, она још увек није резултирала неким јединственим ставом. Деценијама преовлађујући приступ према којем између менацмента/меначера и лидерства/лидера не постоји знак једнакости, током последњих година уступа место другачијем приступу који истиче висок ниво преклапаға и сличности између наведених категорија. У раду се ова два приступа само условно означавају као традиционални и савремени и истовремено се указује на њихову суштину. Аутор овог рада сматра да су све

\footnotetext{
${ }^{1}$ simivana68@gmail.com, ORCID ID 0000-0002-2167-9791,

${ }^{2}$ The paper is a result of research based on the obligation arising from the Agreement (number 451-0368/2020-14/200100), signed by the Ministry of Education, Science and Technological Development of the Republic of Serbia and the Faculty of Economics, University of Niš.
} 
оне анализе које приликом разматрања односа између менаимента/менаиера и лидерства/лидера не узимају у обзир чињенииу да је у организачијама могуће идентификовати два изражена типа лидерства/лидера (формално и неформално) мањкаве и некомплетне. У раду се истиче да однос између менацмента/менацера и формалног лидерства/лидера није идентичан односу који постоји између менацмента/менацера и неформалног лидерства/лидера.

Кључне речи: менацер, лидер, традиционални приступ, савремени присуп.

\section{Introduction}

Although the management practice, manifested through the application of certain management techniques, dates back to ancient civilizations (Pindur et al., 1995, p. 59), and the beginnings of management theory to the second half of the nineteenth century, the more intensive usage of the term management started right after the Second World War (Engwall et al., 2016, p. 1). The upward line in the theoretical and practical utilization of the expression "management" has resulted in numerous, but also very different interpretations of many issues closely related to it. Some of these differences can be the result of various approaches to certain management topics, addressed by individual management theorists. Other can be identified as a consequence of the evolutionary character of management itself, as well as of the critical attitudes towards the content that management theory offers.

Regardless of the variety of the reasons that induce heterogeneity in the interpretation of particular management subjects, its general consequences are, more or less, expected. Although the differences in opinions can lead to progress and to further development of management science, they may lead also to a confusion generated by difficulties or inability to objectively examine certain categories relevant not only to management theory, but also to management practice.

The aim of the paper is to explain the origin and character of one out of many confusions within management theory and, hopefully, to point out the possibility of its resolution. The emphasis is on the perplexity that manifests itself by different interpretations of the relationship between management/manager and leadership/leader. Starting from the fact that the mentioned confusion is, to a certain extent, caused by the differences in the manner in which management/managers and leadership/leaders are determined, the section that follows points out to them firstly. Thereafter, different approaches are presented to illustrate the range of the ways in which management theorists have explained the relationship between management/manager and leadership/leader. In the concluding part the opinion of the author of the paper regarding the relationship between management/manager and leadership/leader is presented.

\section{The confusion in management science}

There is still no consensus among management theorists with regard to how management and manager should be defined. Regardless of the plethora of the literature 
devoted to that issue, the theory of management still does not offer any single, universal, or generally acceptable definition of the mentioned categories. Most authors who have made an effort to define management have done it from their own point of view and with the possible "reliance" on one of, often subjectively selected and at the specific moment prevailing, definitions of management. Therefore, in the abundance of definitions that can be found in the literature, there are those that are similar to each other, as well as those that differ significantly. A chronological overview of some of them, offered by certain most prominent management theoreticians, are presented in the text that follows.

Frederick Winslow Taylor, one of the founders of management science defined management as: "The art of... knowing what you want man to do, and then seeing that they do it in the best and cheapest way" (Kaehler \& Grundei, 2018, p 22). As an "art", management is also defined by Taylor's contemporary Mary Parker Follett. She described management as "the art of getting things done through people" (Stoner \& Freeman, 1989). Opposite to the aforementioned, but also mutually different, are the definitions of management created in the last decades of the twentieth century. Thus, for example, Peter F. Drucker believes that management is: "the specific organ of the new institution whether business enterprises or university, hospital or armed service, research lab or government agency... It devotes a social position and rank but also a discipline and field of study" (Drucker, 1986, p. 9).

On the other hand, Rendal B. Dunham and John Lepley Pierce define management as: "the process of planning, organizing, directing, and controlling organizational resources (human, financial, physical, and informational) in the pursuit of organizational goals" (Dunham \& Pierce, 1989, p. 6). Donald C. Mosley, Paul H. Pietri and Leon C. Megginson point out that the management is: "the process of planning, organizing, leading, and controlling the activities of employees in combination with other resources to achieve organizational objectives" (Mosley et al., 1996, p. 15).

Even the first decades of the twenty-first century have not resulted in formulation of any universal or unique definition of management. Thus, for example, Stephen P. Robbins and Mary Coulter advocate that: "Management involves coordinating and overseeing the work activities of others so that their activities are completed efficiently and effectively" (Robbins \& Coulter, 2012, p. 8). The same authors perceive the manager as "someone who coordinates and oversees the work of other people so that organizational goals can be accomplished" (Robbins \& Coulter, 2012, p. 8). On the other hand, Derek Rollinson (2005) defines the manager as: "a person formally appointed to a role in the organisational hierarchy, associated with which is the formal authority (within prescribed limits) to direct the actions of subordinates. Among other things the role is concerned with some combination of planning, organising, directing and controlling the activities of human resources towards the achievement of set organisational objectives" (Rollinson, 2005, p. 346).

Samuel C. Certo and S. Trevis Certo define management as "the process of reaching organizational goals by working with and through people and other organizational resources" (Certo \& Certo, 2012, p. 7). John R. Schermerhorn, Jr. asserts that "Management is the process of planning, organizing, leading, and controlling the use of resources to accomplish performance goals" (Schermerhorn, 2013, p. 14), while "A manager is a person who supports, activates, and is responsible for the work of others" (Schermerhorn, 2013, p. 14). Richard L. Daft highlights that management is "the 
attainment of organizational goals in an effective and efficient manner through planning, organizing, leading, and controlling organizational resources" (Daft, 2016, p. 4).

It is obvious that the differences in management definitions are more noticeable if we compare definitions made in the first half of the twentieth century with those created at the end of the twentieth or at the beginning of the twenty-first century. These differences might be the result of not only more complete perception of the character of management, but also the consequence of the evolution of management itself.

The different definitions of management, as well as managers, are just one of the reasons which, consequently, led to a divergent understanding of many other categories within management theory, or categories closely related to management. One of such categories, which has deepened the confusion in management theory, is leadership, as well as the terms closely related to it (e.g. leading, leaders).

Although leadership, as a theme, is mentioned in different disciplines (management, psychology, sociology, political science, public administration, and educational administration) (Van Fleet, 1975, p. 40), which to a certain extent limits the possibilities for its unique definition, the fact is also that within one and the same discipline (such as management) leadership is defined differently. According to R. M. Stogdill, "there are almost as many definitions of leadership as there are persons who have attempted to define the concept" (Stogdill, 1974, p. 7). Only several definitions of leadership and leaders which are present in management theory, are offered in the text that follows.

So, for example, John. P. Kotter (1988) defines leadership as: "the process of creating a vision for others and having the power to translate it into a reality and sustain it" (Rollinson, 2005, 341). Gary Yukl and David Van Fleet (1992) consider leadership as: "a process that includes influencing the task objectives and strategies of a group or organization, influencing people in the organization to implement the strategies and achieve the objectives, influencing group maintenance and identification, and influencing the culture of the organization" (Yukl, Van Fleet, 1992, p. 149).

Donald C. Mosley and his colleagues determine leadership as: "A process of influencing individual and group activities toward goal setting and goal achievement" (Mosley et al., 1996, p. 393). The same authors define leading as: "The management function of influencing employees to accomplish objectives, which involves the leader's qualities, styles, and power as well as the leadership activities of communication, motivation and discipline" (Mosley et al., 1996, p. 16).

Stephen P. Robbins and Timothy A. Judge defined leadership and leading in the similar way. According to the mentioned authors leadership is "the ability to influence a group toward the achievement of a vision or set of goals" (Robbins \& Judge, 2017, p. 419), while leading is "a function that includes motivating employees, directing others, selecting the most effective communication channels, and resolving conflicts" (Robbins \& Judge, 2017, p. 41).

According to Derek Rollinson (2005) leadership is: "a process in which leader and followers interact in a way that enables the leader to influence the actions of the followers in a non-coercive way, towards the achievement of certain aims of objectives" (Rollinson, 2005 , p. 342). The same author claims that the leader is: "someone who occupies a role which involves conforming to a set of behaviourial norms and expectations emanating from followers, in return for which they confer on the leader a degree of power that (within prescribed limits) allows the leader to influence their actions" (Rollinson, 2005, p. 346). 
Bruce E. Winston and Kathleen Patterson point out that the leader is: “... one or more people who select, equips, trains, and influeces one or more follower(s) who have diverse gifts, abilities, and skills and focuses the follower(s) to the organization's mission and objectives causing the follower(s) to willingly and enthusiastically expand spiritual, emotional, and physical energy in a concerted coordinated effort to achieve the organizational mission and objectives" (Winston \& Patterson, 2006, p. 7).

The above, as well as many other definitions of leadership/leaders that exist in theory (Berber et al., 2019, p. 169), are dominantly related to the so-called formal leadership, or formal leaders. Parallelly with the formal within the organization exists and significantly affects its business the so-called informal leadership and informal leaders. The fact is that the largest number of research on leadership within the organizational environment is dedicated to formal leadership and formal leaders (Stincelli, Baghurst, 2014 , p. 2). Also, the fact is that between formal and informal leadership/leaders there are significant differences, and that these two types of leadership and leaders cannot be treated in the same way.

The differences in definitions of management/manager, as well as dissimilarities in leadership/leader definitions, with dominant focus on the formal and negligence of the informal leadership/leader, can only be considered as some of the reasons that caused a formidable confusion in the theoretical interpretation of the relationship between management/manager and leadership/leader. The great interest of theoreticians for this relationship enabled the identification of two dominant approaches. In this paper, these two approaches are designated as traditional, on the one hand, and contemporary, one the other. Their essence is presented in the section that follows.

\section{Management/managers vs. leadership/leaders: the traditional approach}

A more intense debate about the relationship between management/manager and leadership/leader in terms of their conceptual delineation began in 1977 when Harvard Business Review released the paper "Managers and Leaders: Are They Different?" authored by Abraham Zaleznik (Zaleznik, 2001). In this paper, for the first time, management and leadership are treated as "two separate functions" (Azad et al., 2017, p. 1). By specifying the differences between managers and leaders in detail, Zaleznik points out that they are primarily concerned with (Table 1): attitudes towards goals, conceptions of work, relations with others and sense of self (Zaleznik, 2001).

After Zaleznik, the view that there is a clear and obvious distinction between management/manager and leadership/leaders has been advocated by many other theorists. One of the most famous is certainly John P. Kotter (Kotter, 1990; Kotter, 2001). His book "A Force for Change: How Leadership Differs From Management," (1990) is devoted to explaining the character of the mentioned difference. At the very beginning of the book, Kotter indicates that, in the daily conversation, the term leadership is used in two different ways or two different meanings. In the first, leadership is used to designate "a process that helps direct and mobilize people and/or their ideas" (Kotter, 1990, p. 3). In the other, leadership is used to point out "a group of people in a formal position" (Kotter, 1990, p. 3 ). The latter way of using the term leadership was categorically rejected by Kotter with 
the explanation that, in his opinion, some people in a formal position "lead well, some lead poorly, and some do not lead at all” (Kotter, 1990, p. 3). Consequently, although Kotter is completely aware of the fact that "the majority of people who are in positions of leadership today are called managers ..." (Kotter, 1990, p. 3), which coincides with the latter meaning of the term leadership, Kotter states that such an understanding of leadership is not acceptable to him because it "suggests that leadership and management are the same thing ..." (Kotter, 1990, p. 3).

Table 1: Managers vs. Leaders

\begin{tabular}{|c|c|c|}
\hline & MANAGERS & LEADERS \\
\hline $\begin{array}{l}\text { ATTITUDES TOWARD } \\
\text { GOALS }\end{array}$ & $\begin{array}{c}\text { Goals arise out of necessities, not } \\
\text { desires }\end{array}$ & $\begin{array}{l}\text { Take a personal, active outlook. } \\
\text { Shape rather than respond to ideas. } \\
\text { Alter moods, evoke images, } \\
\text { expectations. } \\
\text { Change how people think about } \\
\text { what is desirable and possible. Set } \\
\text { company direction. }\end{array}$ \\
\hline $\begin{array}{l}\text { CONCEPTIONS OF } \\
\text { WORK }\end{array}$ & $\begin{array}{l}\text { Negotiate and coerce. Balance } \\
\text { opposing views. } \\
\text { Design compromise. Limit choices. } \\
\text { Avoid risk. }\end{array}$ & $\begin{array}{c}\text { Develop fresh approaches to } \\
\text { problems. } \\
\text { Increase options. Turn ideas into } \\
\text { exciting images. } \\
\text { Seek risk when opportunities appear } \\
\text { promising. }\end{array}$ \\
\hline $\begin{array}{l}\text { RELATIONS WITH } \\
\text { OTHERS }\end{array}$ & $\begin{array}{c}\text { Prefer working with people, but } \\
\text { maintain minimal emotional } \\
\text { involvement. Lack empathy. } \\
\text { Focus on process, eg. how } \\
\text { decisions are made rather than what } \\
\text { decisions to make. } \\
\text { Communicate by sending } \\
\text { ambiguous signals. Subordinates } \\
\text { perceive them as inscrutable, } \\
\text { detached, manipuative. } \\
\text { Organization accumulates } \\
\text { bureaucracy and political intrigue. }\end{array}$ & $\begin{array}{l}\text { Attracted to ideas. Relate to others } \\
\text { directly, intuitively, empathetically. } \\
\text { Focus on substance of events and } \\
\text { decisions, including their meaning } \\
\text { for paricipants. } \\
\text { Subordinates describe them with } \\
\text { emotionally rich adjectives; e.g. } \\
\text { «love», «hate». Relations appear } \\
\text { turbulent, intense, disorganized. Yet } \\
\text { motivation intensifies, and } \\
\text { unanticipated outcomes proliferate. }\end{array}$ \\
\hline \multirow[t]{2}{*}{ SENSE OF SELF } & $\begin{array}{l}\text { Comes from perpetuating and } \\
\text { strengthening existing institutions. }\end{array}$ & $\begin{array}{c}\text { Comes from struggles to profoundly } \\
\text { alter human and economic } \\
\text { relationships. }\end{array}$ \\
\hline & Feel part of the organization. & Feel separate from the organization. \\
\hline
\end{tabular}

Source: based on Zaleznik, 2001, p. 1.

Based on such one-dimensional perception of leadership (which takes into consideration only one of the meanings of leadership and neglects other ones) John P. Kotter specifies the key differences between leadership and management (Table 2).

After such an obviously incomplete explanation of the relationship between leadership and management, John P. Kotter points out that it is necessary to establish a close link between them. In this regard, he states that: "This does not mean that 
management is never associated with change; in tandem with effective leadership, it can help produce a more orderly change process. Nor does this mean that leadership is never associated with order; to the contrary, in tandem with effective management, an effective leadership process can help produce the changes necessary to bring a chaotic situation under control" (Kotter, 1990, p. 7). It is obvious that although Kotter insists on the differences between management and leadership, he simultaneously points to their mutual complementarity in the organizational environment.

Table 2: Comparing Management and Leadership

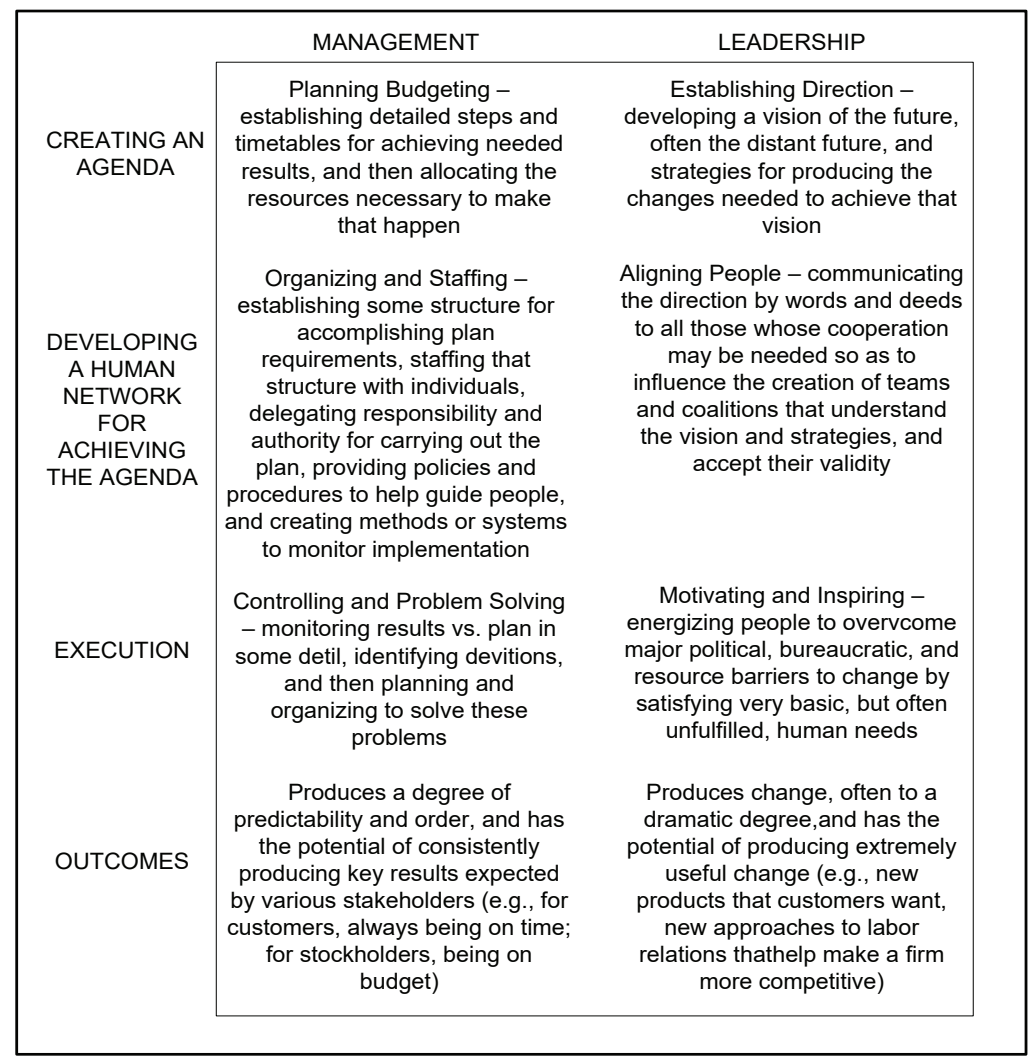

Source: Kotter, 1990, p. 6.

The opinion that leaders and managers are different is also represented by many other authors (Bennis \& Nanus, 1985; Toor \& Ofori, 2008; Fairholm, 2002; Baruch, 1998). Thus, for example, pointing to the difference between managers and leaders, Warren Bennis and Burt Nanus emphasize that: "managers are masters of routine, they accomplish, they are efficient; whereas leaders are masters of change, they influence, they are effective" (Bennis \& Nanus, 1985, p. 21).

Starting from the viewpoint that leadership and management are "two completely different functions," and managers and leaders are "not the same people", ShamasUr-Rehman Toor and George Ofori point out the conceptual, definitional, functional, 
etymological, development and behavioral differences between those processes, as well as between their key subjects (Toor \& Ofori, 2008, p. 61). Regardless of the identified differences, Toor and Ofori note that today's organizations need "leaders with managerial capabilities and managers with leadership qualities" (Toor \& Ofori, 2008, p. 69).

It is obvious that the foregoing theoreticians insist on a clear distinction between management/manager and leadership/leader. At the same time, they point to the mutual complementarity of management and leadership, as well as to the necessity of simultaneous presence of managers and leaders within the organization (Kotter, 1990, p. 7; Toor \& Offori, 2008, p. 69). Moreover, some of them consider that the functions of managers and leaders within the organization can be performed by one and the same person (Fairholm, 2002, p. 8). The aforementioned, only as one of the dilemmas impose the following: if managers and liders are different, how can one person be both manager and leader at the same time?

The explanations of the foregoing theoreticians about the relationship between management/manager and leadership/leader, are in the paper only conditionally classified into the so-called traditional approach. Although the author of this paper considers that those explanations contain some limitations, a dose of abstraction, illogicality and obvious inconsistency (which creates a sort of confusion concerning the relationship between management/manager and leadership/leaders), mentioned features are not of the crucial importance for the author to classify these explanations into the so-called traditional group. Namely, the key criterion for their classification in the traditional approach is chronological, more precisely the first time those confusing explanations of the relationship between management/manager and leadership/leader have appeared in the literature.

\section{Management/managers vs. leadership/leaders: the contemporary approach}

Confusing stances offered by the representatives of the traditional approach have launched a debate about their validity and sustainability (Mabey, 2007). As a result of not only a critical attitude towards the traditional approach, but also as a consequence of more objective observations of the characteristics of contemporary organizations, the quality of modern managers, as well as the demands imposed on today's managers, a different approach has appeared in the literature (see: Kolodziejczyk, 2015, p. 123). In the paper that approach is only conditionally designated as a modern or contemporary one. It advocates the practical inseparability of leadership from management. Considering the manner in which the interconnection between leadership and management is explained, it is possible to identify two variants within this approach.

One of the variants of the modern approach (to the relationship between management/manager and leadership/leader) is the one according to which the leadership is considered as just one out of the four sub-processes within the management process, while leadership qualities are attributed to managers. The vision of management as a process that, in addition to planning, organizing and controlling, also includes leadership, and the manager as a subject simultaneously responsible for the management process and for the leadership sub-process, are advocated by the authors (Mosley et al., 1996; 
Gulati, et al., 2017) whose view is primarily based on some of more current and dominant management definitions.

So, for example, in their book "Management: Leadership in Action" Donald C. Mosley and his colleagues emphasize that leadership is only part of management and that management, apart from leadership, also includes other management functions (planning, organizing and controlling) (Mosley et al., 1996, p. 393). At the same time, Mosley and his colleagues point out to the extraordinary importance that leadership has for the successful accomplishment of entire management function. For the purpose of emphasizing that significance, in the aforementioned book, Mosley and his colleagues use the terms manager and leader alternately whenever they talk about managers (Mosley et al., 1996, p. 19). In doing so, they are completely aware of the fact that they interpret leadership in a more comprehensive way which, objectively speaking, is not inherent to it (Mosley et al., 1996, p. 393).

Ranjay Gulati and his colleagues (2017) point out that "the distinction between management and leadership is often very subtle" as well as that "most people use the terms interchangeably (when they refer to the operation of a business)" (Gulati et al., 2017, p. 8). Gulati and his colleagues consider that the so-called leadership skills are inherent to managers. Namely, starting from the fact that one of the traditional categorization of managerial skills includes: technical, interpersonal and conceptual skills, Gulati and his colleagues believe that leadership skills are identical to interpersonal managerial skills (Gulati et al., 2017, p. 9).

The second option of the modern approach to the relationship between management and leadership is based on the view that management and leadership are two identical processes, that is, managers and leaders are one and the same. Thus, for example, Boris Kaehler and Jens Grundei consider that making any difference between management/ manager and leadership/leader is illogical and artificial and, as such, it should be abandoned (Kaehler \& Grundei, 2018, p. 13-14). Namely, the mentioned authors consider that it is impossible to observe leadership isolated from the other management functions (planning, organizing and controlling). In other words, except from "leading people", leaders should also plan, organize and control resources and activities within organization. On the other hand, according to Kaehler and Grundei, managers can not be distanced from leading people. Therefore, the two authors claim that management and leadership are one and the same concept and that any idea of their mutual separation should be abandoned (Kaehler \& Grundei, 2018, p. 14). At the same time, Kaehler and Grundei state that there are very few contemporary authors who, like them, equalize leadership and management. Henry Mintzberg is one of them (Kaehler \& Grundei, 2018, p. 14).

Henry Mintzberg believes that although it is conceptually possible to make a certain distinction between leadership and management, in practice such a dissimilarity is not feasible, nor necessary, and admits that he even does not understand the attempts to make such a delineation: "Frankly, I don't understand what this distinction means in the everyday life of organizations... How would you like to be managed by someone who doesn't lead? ... Well, then, why would you want to be led by someone who doesn't manage?" (Mintzberg, 2009, p. 8)

The view that management and leadership are one and the same is also represented by a group of authors in their paper "Leadership and Management Are One and the Same" 
(Azad et al., 2017). Based on a detailed research of the literature dedicated to the terms: lead, leading, leadership, leader, manage, management, management, and manager, within the respective databases (PubMed, EBSCO, Scopus, Emerald, JSTOR, Business Source Premier, Google Scholar, and ERIC) (Azad et al., 2017, p. 1), the authors of the mentioned paper conclude that "no scientific evidence exists to support the described differences between leadership and management ..." (Azad et al., 2017, p. 1). The same authors claim that leadership and management are not only complementary, but that, in fact, they represent one and the same concept. They point out that, even if it is possible to separate these two concepts in theory, it is impossible to separate them in practice. In doing so, they particularly emphasize the practical inseparability of leadership from management within a high-performing organization. In this context, they state that, in theory separately identified skills necessary for the successful realization of management and leadership functions, in practice manifest themselves through an inseparable continuum created between these functions (Table 3) (Azad et al., 2017, pp. 1-2).

Table 3: Leadership and Management Continuum

\begin{tabular}{|ll|}
\hline LEADERSHIP & MANAGEMENT \\
\hline Focuses on people & Focuses on things \\
Articulates a vision & Executes plans \\
Trusts \& develops & Directs \& coordinates \\
Creates change & Manages change \\
Uses influence & Uses authority \\
Authority comes from & Authority stems from position in \\
personal relationships & the organization \\
Thinks strategically & Determines long-term objectives \\
& and strategies \\
Delegates responsibility & Acts decisively \\
Appropriate risk taking and & Decides how to use personnel \\
innovation & and other resources \\
\hline
\end{tabular}

Source: Azad et al., 2017.

The stance that managers are leaders at the same time, is also present in some practical research. Thus, for example, in one of them which was dedicated to the testing of leadership power, conducted by the Center for Creative Leadership, it was stated that "the respondents in that research were primarily managers" (Bal, et al., 2008, p. 6).

\section{Conclusion}

Regardless of the abundance of the opinions offered within the two presented approaches, the author of this paper considers that it is not possible to accept any of them completely and without any limitations. The key reason is that all of the presented opinions are predominantly based on the analysis of the relationship between management/manager and the so-called formal leadership/leader, ignoring the fact that within the organization, in parallel with formal, there are also informal leaders and informal leadership. The processes of formal and informal leadership are different processes within the organization. There is also a significant difference between formal 
and informal leaders as subjects primarily responsible for these processes. It turns out that the relationship between management/manager and formal leadership/leader is not identical to the relationship that exists between management/manager and informal leadership/leader. In that sense, the mentioned relations can not be interpreted correctly in a unique way.

When it comes to the relationship between management/manager and formal leadership/leader, management can be considered as a wider and more comprehensive concept. Namely, regardless of the differences between theoreticians in terms of how to define management, according to the most current definitions, management is perceived as a process that includes planning, organizing, leading, and controlling, as its key subprocesses, while the manager is mentioned as the only subject responsible for the overall management process. In order to be able to successfully accomplish the activities that form the content of the formal leadership sub-process, the manager must, among other things, have at his/her disposal the sets of those qualities (knowledge and skills) that any leader should have (for example, an informal leader within the organization, political leader, a leader in a society, etc.).

Due to the above mentioned, in management theory, but also in management practice, it is not recommended to insist on the category of formal leaders within the organization. According to the author of this paper, such insistence only encourages further confusion regarding the relationship between management/manager and leadership/leader.

The character of the relationship between management/manager and informal leadership/ leader is different. It happens that, besides formal, it is possible to identify the informal leadership processes within organization. Those processes are not an integral part of the management process. Therefore, the flows and activities of informal leadership processes in the organization are not directed by managers, but by informal leaders. Any member of the organization can be an informal leader. It turns out that the processes of management and informal leadership are not interconnected, as well as that, managers are not the same as informal leaders.

\section{References}

Azad, N., Anderson, H. G. Jr., Brooks, A., Garza, O., O’Neil, C., Stutz, M. M., \& Sobotka, J. L. (2017). Leadership and Management Are One and the Same. American Journal of Pharmaceutical Education, 81(6), Article 102, 1-5. Retrieved from https://www.ajpe.org/doi/pdf/10.5688/ajpe816102

Bal, V., Campbell, M., Steed, J., \& Meddings, K. (2008). The Role of Power in Effective Leadership. Center for Creative Leadership. Retrieved from www.ccl. org/wp-content/uploads/2015/04/roleOfPower.pdf

Baruch, Y. (1998). Leadership - Is That What We Study? The Journal of Leadership Studies, 5(1), 100-124.

Bennis, W., \& Nanus, B. (1985). Leaders: The Strategies for Taking Change. New York: Harper-Collins Publisher

Berber, N., Slavić, A., Miletić, S., Simonović, Z. \& Aleksić, M. (2019). A Survey on Relationship between Leadership Styles and Leadership Outcomes in the Banking Sector in Serbia. Acta Polytechnica Hungarica, 16(7): 167-184. 
Bobera, D., Strugar-Jelača, M. \& Bjekić, R. (2017). Analysis of leadership styles in medium and large companies on the territory of the Republic of Serbia. Anali Ekonomskog fakulteta u Subotici, (37), 117-127.

Certo, S. C., \& Certo, S. T. (2012). Modern Management: Concepts and Skills. New Jersey: Pearson Education, Inc.

Daft, R. L. (2016). Management. Boston: Cengage Learning.

Drucker, P. F. (1986). Management: Task, Responsibilities, Practices. New York: Truman Talley Books, E. P. Dutton.

Dunham, R. B., \& Pierce, J. L. (1989). Management. Glenview, Illinois: Scott, Foresman \& Company.

Engwall, L., Kipping, M., \& Üsdiken, B. (2016). Defining Management: Business Schools, Consultants, Media. New York: Routhledge, Taylor \& Francis Group.

Fairholm, M. R. (2002). Defining Leadership: A Review of Past, Present, and Future Ideas. Washington: Center for Excellence in Municipal Management. Retrieved from https://www.researchgate. net/profile/Matthew_Fairholm/publication/283048404_Defining _ Leadership/links/56278d6d08aed9017d45f3d9/Defining-Leadership. pdf?origin=publication_detail

Gulati, R., Mayo, A. J., \& Nohria, N. (2017). Management: An Integrated Approach. Boston: Cengage Learning.

Kaehler, B., \& Grundei, J. (2018). HR Governance: A Theoretical Introduction. Springer. Retrieved from https://www.researchgate.net/publications/326844028 HR_Governance_A_Theoretical_Introduction

Kolodziejczyk, J. (2015). Leadership and Management in the Definitions of School Heads. Athens Journal of Education, 2(2), 123-136.

Kotter, J. P. (1990). A Force for Change: How Leadership Differs From Management. New York: The Free Press.

Kotter, J. P. (2001). What Leaders Really Do? Harvard Business Review (Reprint RO111F), December. Retrieved from https://www.ndti.org.uk/uploads/files/ HBR_What-Leaders-Really-Do.pdf

Kumle, J., \& Kelly, N. J. (1999). Leadership versus management. Supervision, 61(4). 8-10.

Mabey, C. (2007). Developing Effective Managers and Leaders. Edinburgh: Edinburgh Business School.

Mintzberg, H. (2009). Managing. San Francisco: Berret-Koehler Publishers.

Mosley, D. C., Pietri, P. H., \& Megginson L. C. (1996). Management: Leadership in Action. HarperCollins College Publishers Inc.

Pielstick, C. D. (2000). Formal vs. Informal Leading: A Comparative Analysis. (2000). Working Paper Series 00-04-Sept2000. Retrieved from http://openknowledge. nau.edu/1643/7/Pielstick_CD_2000_FrankeWPS_00-04\%281\%29.pdf

Pindur, W., Rogers, S. E., \& Kim, P. S. (1995). The history of management: a global perspective. Journal of Management History, 1(1), 59-77. 
Robbins, S. P., \& Coulter, M. (2012). Management. New Jersey: Pearson Education, Inc.

Robbins, S. P., \& Judge, T. A. (2017). Organizational Behavior. Pearson.

Rollinson, D. (2005). Organisational Behaviour and Analysis: An Integrated Approach. London: Financial Times Prentice Hall.

Schermerhorn, J. R. Jr. (2013). Management: Learn, Succeed. USA: John Wiley \& Sons, Inc.

Stincelli, E., \& Baghurst, T. (2014). A Grounded Theory, Exploration of Informal Leadership Qualities as Perceived by Employees and Managers in Small Organizations. International Journal of Business Management and Economic Research (IJBMER), 5(1), 1-8.

Stogdill, R. M. (1974). Handbook of Leadership: A Survey of the Literature. New York: Free Press.

Stoner, J. A. F., \& Freeman R. E. (1989). Management. Englewood Cliffs, New Jersey: Prentice-Hall.

Toor, S. U. R., \& Ofori, G. (2008). Leadership versus management: How They Are Different, and Why. Leadership and Management in Engineering. April, 61-71.

Van Fleet, V. D. D. (1975). Changing patterns of significant authors on leadership and managerial effectiveness. Journal of Management, 1, 39-44.

Winston, B. E., \& Patterson, K. (2006). An Integrative Definition of Leadership. International Journal of Leadership Studies, 1(2), 6-66.

Yukl, G., \& Van Fleet, D. D. (1992). Theory and Research on Leadership in Organizations. M. D. Dunnette and L. M. Hough (Ed.), Handbook of Industrial and Organizational Psychology (pp. 147-197). Palo Alto, California: Consulting Psychologists Press, Inc.

Zaleznik, A. (2001). Managers and Leaders: Are They Different? Harvard Business Review, HBR Classic. Reprint RO401G. Retrieved from http://websites.uwlax. edu/kincman/390\%20Paperwork/Managers\%20and\%20Leaders\%203.pdf 